Original Paper http://ajol.info/index.php/ijbcs http://indexmedicus.afro.who.int

\title{
Diversity of hemipterans and ants in a market-gardening based agro-system in a suburb of Yaoundé, Centre Region (Cameroon)
}

\author{
Désirée Chantal ALÉNÉ*, Yveline MATCHINDA MOUKEM, Zéphirin TADU and \\ Champlain DJIÉTO-LORDON
}

\author{
University of Yaoundé I, Faculty of Science, Laboratory of Zoology, Department of Animal Biology and \\ Physiology, P. O. Box 812 Yaoundé, Cameroon. \\ *Corresponding author; E-mail: chantalalene@yahoo.fr; Phone: (+237) 697994932.
}

\begin{abstract}
Hemipterans are sap sucking insects that may seriously affect their host-plants' fitness in case of population outbreaks. They are often associated with various ant species that feed on the honeydew they produce. These two insect taxa are highly diversified, but poorly documented in market crop environment of tropical Africa. In order to improve knowledge on these potential pests, they were sampled twice per week on five plant species including Abelmoschus esculentus, Capsicum annuum, Solanum lycopersicum, Solanum melongena and Solanum scabrum in a trap garden settled at Nkolondom, a north-western suburb of Yaoundé, from July to October 2013. As result, the hemipteran community was dominated by aphids (Aphididae), $v z$ Aphis fabae, Aphis gossypii and Aulacorthum solani on S. scabrum, A. esculentus and C. annuum respectively, and Macrosiphum euphobiae on S. melongena and L. esculentum; scale insects and mealybugs (Coccoidea), the whitefly Bemisia tabacci (Aleyrodidae) on C. annuum. Leafhoppers (Cicadelidae) and treehoppers (Membracidae) occurred preferentially on S. melongena and A. esculentum. Some true bugs (Heteroptera), $v z$ Miridae, Pentatomidae, Pyrrhocoridae and Reduviidae were recorded mainly on okra. The ant community was mostly represented by honeydew feeding species among which Myrmicaria opaciventris, Camponotus flavomarginatus, Pheidole megacephala and Technomyrmex sp.
\end{abstract}

(C) 2019 International Formulae Group. All rights reserved

Keywords: Sap sucking insects, aphids, Formicidae, market crops, inventory.

\section{Diversité des hémiptères et des fourmis dans un agrosystème à base de cultures maraîchères dans une banlieue de Yaoundé, Région du Centre (Cameroun)}

\section{RESUME}

Les hémiptères sont des insectes suceurs de sève capables d'affecter sérieusement le fitness de leurs plantes hôtes en cas de fortes pullulations. Ils sont souvent associés avec diverses espèces de fourmi qui se nourrissent du miellat qu'ils produisent. Ces taxa sont très diversifiés, mais faiblement étudiés en milieu maraîcher en Afrique tropicale. Dans le but d'améliorer les connaissances sur ces potentiels ravageurs, ils ont été échantillonnés deux fois par semaine sur cinq espèces de plantes dont Abelmoschus esculentus, Capsicum annuum, Solanum lycopersicum, Solanum melongena et Solanum scabrum dans un jardin expérimental à 
Nkolondom, périphérie nord-ouest de Yaoundé, entre Juillet et Octobre 2013. Comme résultat, la communauté des hémiptères était dominée par les pucerons (Aphididae), Aphis fabae, Aphis gossypii et Aulacorthum solani sur S. scabrum, A. esculentus et $C$. annuum respectivement, et Macrosiphum euphobiae sur S. melongena et $S$. lycopersicum; des cochenilles (Coccidae et Pseudococcidae) et la mouche blanche Bemisia tabacci (Aleyrodidae) ont été trouvés sur $C$. annuum; des Membracidae et des Cicadelidae ont préférentiellement été trouvés sur S. melongena et A. esculentum quelques hétéroptères (Miridae, Pentatomidae, Pyrrhocoridae et Reduviidae) ont principalement été observés sur le gombo. La communauté de fourmi comprenait surtout des espèces mielliphages telles Myrmicaria opaciventris, Camponotus flavomarginatus, Pheidole megacephala et Technomyrmex sp.

(C) 2019 International Formulae Group. All rights reserved

Mots clés : Insectes suceurs de sèves, pucerons, Formicidae, cultures maraîchères, inventaire.

\section{INTRODUCTION}

In Cameroon, urban and peri-urban market gardening is considered among the main sources of vegetable supply of major cities, thus contribute to ensure food security (Temple, 2001). Moreover, market gardening provides employment for the youths and supplementary incomes for public or/and private sectors' workers with very low revenues (Temple et al., 2008). It is the case in the main production zones in western highlands and in the peri-urban areas around major cities such as Yaoundé and Douala (Kahane and Temple, 2004). Intensive and permanent market crop systems have led to the development of a diversified associated insect fauna (Djiéto-Lordon et al., 2007). Direct or indirect damages due to depredator insects are among the main constraint to the development of these activities (Heumou et al., 2015, Elono Azang et al., 2016). Since the year 2000, our team has undertaken inventories of insect associated with market gardening system in order to provide annotated check lists (Djiéto-Lordon et al., 2007, Djiéto-Lordon et al., 2014). These inventories were followed by some biological and ecological studies on insect pests (Hemou et al., 2015; Elono Azang et al., 2016).

Sap-suckers (Hemiptera) appeared among the major components of this community although poorly documented. Their damages are not obvious; however, they may be harmful since they are very prolific and usually determine outbreaks, leading to growth distortions, leaf curling, and withering of attacked organs on their host-plants (Guerrieri and Digilio, 2008). In fact their sucking activity may disrupt sap transportation in conducting vessels and affect dissemination of nutrients it contains. Hence, they are known to have a great negative impact on cash crops such as Cocoa (Mahob et al., 2014, 2018). Likewise, as they introduce toxic saliva (Cooper et al., 2010), they may act as vectors of some pathogenic microorganisms, mainly viruses to plants (Blackman \& Eastop, 2000; Brault et al., 2010; Camara et al., 2016). Some welldocumented examples are Soybean mosaic virus and Alfalfa mosaic virus (Hill et al., 2001; Clark and Perry 2002), Potato virus Y in potato, Solanum tuberosum L. (Davis et al., 2005), Cucumber mosaic virus in snap bean, Phaseolus vulgaris L. (Gildow et al. 2008).

Some of these hemipterans are often encountered with ants which are closely or not associated with them (Delabie, 2001; Steiner et al. 2004; Moreira and Del-Claro, 2005; Oliver et al., 2007). These ants are likely to disseminate hemipterans, mainly those belonging to the sub-order Sternorrhyncha, on host-plants and/or protect them by building shelters around their colonies; these shelters are supposed to protect them from their natural enemies or from weather constraints. In turn, hemipterans produce honeydew which is highly prized by ants (Delabie, 2001; Oliver et al., 2007). Owing these considerations ants could also be regarded as indirect pest. 
The present study aimed at providing an inventory of hemipteran and ant fauna associated with market-gardening based agrosystem in a suburb of Yaoundé with further view to understand their association patterns.

\section{MATERIALS AND METHODS}

\section{Study site and period}

The present study was carried out at the campus of the University of Yaoundé 1 $\left(03^{\circ} 51^{\prime} 35,3\right.$ " N; $11^{\circ} 30^{\prime} 0,06$ " $\mathrm{E}$; $770 \mathrm{~m}$ asl) and at Nkolondom $\left(03^{\circ} 57^{\prime} 07^{\prime \prime} \mathrm{N}, 11^{\circ} 29^{\prime}\right.$ 27 'E; $645 \mathrm{~m}$ asl). The locality undergoes an equatorial transitional climate, Guinean type, with a bimodal rainfall regime. This climate is characterized by an average rainfall ranged from 1400 to $1600 \mathrm{~mm} /$ year (Suchel, 1988). Localized in a forest-savannah transition zone (Letouzey, 1985), the ecosystem is heavily disturbed by anthropogenic activities (market oriented gardening and urbanization) so that just a few natural vegetation remains on the hill side. Indeed, market gardens' plots occupy the sides of the small stream that run the entire village.

Farmers grow especially Apium graveolens L. (celery), Amaranthus viridis L. (amaranth), Lactuva sativa L. (lettuce), Solanum scabrum Mill. (African nightshade), Ocimium basilicum L. (basilicum), Petroselinum crispum (Mill.) (Persil), Abelmoschus esculentus (L.) Moench (okra), Solanum lycopersicum (tomato), Solanum melongena L. (sweet eggplant), Solanum aethiopicum L. (African scarlet eggplant) and Cucumis sativus L. (cucumber) (Djiéto Lordon et al., 2007; Mvogo, 2005).

The study was conducted from June $21^{\text {st }}$ to October $12^{\text {th }} 2013$. This period covered the short dry season and the great rainy season. However, data collection was effectively done from July $25^{\text {th }}$ to October $12^{\text {th }}$ 2013.

\section{Plant material}

The biological material involved four Solanaceae, C. апnиum, S. lycopersicum, $S$. scabrum, $S$. melongena and one Malvaceae, $A$. esculentus. These plant species were chosen owing their high and everlasting production in different local market-oriented cropping systems around Yaoundé.

For the experiment, seeds of $S$. lycopersicum, $C$. annuum, $S$. scabrum and $S$. melongena were produced and conditioned by Technisem were bought from Yaoundé market. Varieties used were "roma savanna" for the tomato, Estrella F1 for pepper, "F1 kalenda" for the sweet eggplant and "royale" for the African nightshade. For okra, $A$. esculentus (var paysan), seed locally produced were bought from Mokolo market in Yaoundé.

\section{Experimental design}

A parcel of 10 ridges $(8.5 \mathrm{~m} \mathrm{x} 1 \mathrm{~m})$ separated by furrows of about $0.25 \mathrm{~m}$ wide was set up at Nkolondom. Seedlings were issued from a nursery set up at the campus of the University of Yaoundé 1; they were transplanted on ridges following intervals of $0.75 \mathrm{~m} \times 0.5 \mathrm{~m}$. Each plant species occupied two ridges. Two weeks after the transplantation, the soil was fertilized with the NPK (20-10-10) (about 10g/plant). The transplanted plants were daily watered. The plot was weeded once a week during the study period.

\section{Data collecting}

Data were collected twice per week. For each sampling, 30 plants per species were randomly selected and examined. The inventory was done on the base of presence/absence for each insect species. Once the activity of the insect noted on a hostplant, some specimens were collected for identification purpose and voucher collection of the laboratory.

\section{Identification of collected insects}

At the laboratory, the identification of the material was done by comparing specimens to those in the collection of the Laboratory of Zoology of University of Yaoundé 1 and using the following keys: Couilloud (1989), Blackman and Eastop 
(2000) for hemipteran fauna, Hölldobler and Wilson (1990), Bolton (1994) and Taylor (http:/www.antbase.org/, April, 06 ${ }^{\text {th }}, 2015$ ) for ant fauna. These identifications were later confirmed by comparing specimens to the Voucher collection of the Royal Museum for Central Africa (RMCA) at Tervuren (Belgium) during an internship of DCA. Some other hemipterans such as mealybugs were identified with the help of taxonomists of the CIRAD-CBGP at Montpellier (France) during an internship of DCA.

\section{Data analysis}

Diversity of hemipteran fauna was studied using species richness (S), ShannonWeiver diversity index (H'), maximal diversity (Hmax) and Pielou index (E) for each plant species. Kruskall-wallis test was also used to test the effect of plant species on the variation of the mean species richness, the Shannon-Weiver, the maximal diversity and the Pielou indices; when necessary, Wilcoxon pairwise comparison was applied and P-value adjusted with sequential Bonferroni procedure to find out the difference of each diversity parameter between pairs of plant species.

Beta diversity was evaluated using Analysis of Similarities (ANOSIM). It provides $\mathrm{R}$ statistics which is the measure of the Bray Curtis dissimilarities between hostplant species. The value of $\mathrm{R}$ varies from -1 (lower similarity between group) to 1 (high similarity between group), the value 0 indicating a completely random grouping. All These analysis were done using package Vegan (Oksanen et al., 2011).

The occurrence of each hemipteran species on different host-plants was computed and the effect of plant species on the variation of the most occurring hemipteran species was tested using Chi-squared test (GLM proc) and the binomial family as recommended by Crawley (2007) for the proportion data. TurkeyHSD pairwise comparison test was applied when necessary to find the variation between host-plant pairs. Values of probabilities were adjusted by using the sequential procedure of Bonferroni for pairwise comparisons and the results were appreciated at the $5 \%$ threshold.

Ant fauna was characterized by evaluating the occurrence of each species on different host-plants. All these analyses were done using the Software R (Wei and Simko, 2017).

\section{RESULTS \\ Hemiptera fauna}

From the entomofauna sampled at Nkolondom on five plant species, hemipterans collected (Table 1) belonged to 31 species from 26 genera and 14 families.

Species richness varied significantly according to crop species $\left(\chi^{2}=47.968 ; \mathrm{df}=4\right.$; $\mathrm{p}<0.0001)$. Solanum melongena was the richest habitat with 22 species whereas $S$. scabrum was the poorest habitat with seven species (Table 2). The pairwise comparison (Kruskal-Wallis rank sum test) arose two groups, the first one (S. melongena) with high species richness were recorded and the second one (A. esculentum, S. scabrum, C. annuиm and $S$. lycopersicum) with low species richness (Table 2). The Shanon-Weiver Index (H') also revealed a highly significant variation according to host-plants $\left(\chi^{2}=\right.$ 32.735; df $=4$; $\mathrm{p}<0.0001)$; pairwise comparison showed that the $S$. melongena habitat was the most diversified. The Hmax index (LogS) showed the same trend as $\mathrm{S}$ and H'. For the Eveness Index of Pielou (J), variations also appeared highly significant according to host-plants $\left(\chi^{2}=80.845 ; \mathrm{df}=4\right.$; $\mathrm{p}<0.0001)$; pairwise comparison allowed pointing out $A$. exculentus as a distinguish group of equitability.

The analysis of similarity (ANOSIM) between the faunal communities of the fivecrop species revealed three different groups $(\mathrm{R}=0.802 ; \mathrm{P}=0.001)$. Solanum melongena appeared significantly isolated from the four other species, while A. esculentum on one hand and S. scabrum, $C$. апnиum and $S$. lycopercicum on the other formed two relatively different groups (Figure 1). These 
trends testify the polyphagous feature of these hemipterans.

\section{Host-plant effect on the variation of aphids occurrence}

Despite the polyphagous feature of the hemipterans, especially aphid species identified, each of them appeared preferentially associated with one specific host-plant, except $M$. euphorbiae which was obviously associated with two host-plants, $S$. melongena and $S$. lycopersicum. For instance, the $\chi^{2}$ analysis showed a highly significant variation in their occurrence depending on host-plants (Table 3).

Damage caused by these aphids on host-plants were really conspicuous, especially leaf rolling up and crinkling due to A. fabae on S. scabrum and fruit deformation due to M. euphorbiae on S. melongena.

\section{Myrmecofauna}

Ants recorded in the present study belonged to 14 species from 10 genera and three subfamilies (Table 4). The most important family was Myrmicinae with 18 occurrences representing a frequency of $100 \%$, followed by Formicinae [16 (88.89\%)] and Dolichoderinae [14 (77.78\%)]. Among them, Camponotus flavomarginatus Mayr 1862 (Formicinae), Myrmicaria opaciventris Emery 1893, Pheidole megacephala F. (Myrmicinae) and Technomyrmex sp. (Dolichoderinae) were the most frequent. The frequency of their occurrence varied significantly from one host-plant to another. Hence, C. flavomarginatus was mostly observed on $S$. melongena and $S$. lycopersicum whereas $M$. opaciventris occurred more frequently on $S$. melongena and S. scabrum; P. megacephala was mostly encountered on $S$. lycopersicum, and Technomyrmex sp. was mostly observed on A. esculentus and S. lycopersicum.

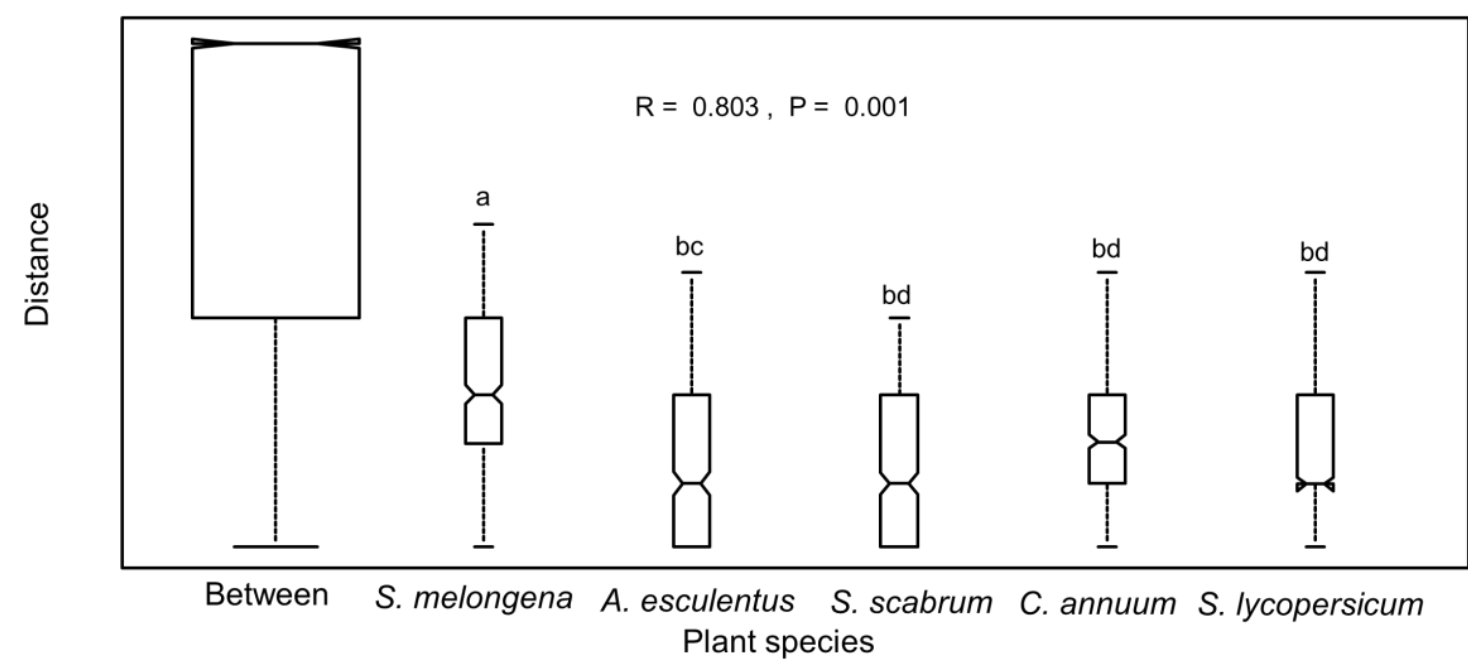

Figure 1: Analysis of the similarity (ANOSIM) between the faunal communities of the fivecrop species. Legend: R: measure of dissimilarity amongst host-plants, P: value of probability. Letters above the boxes indicate differences or similitudes in pairs of studied host-plants after pairwise comparisons. 
Table 1: List of insect species encountered on the five market crop species at Nkolondon from July to October 2013.

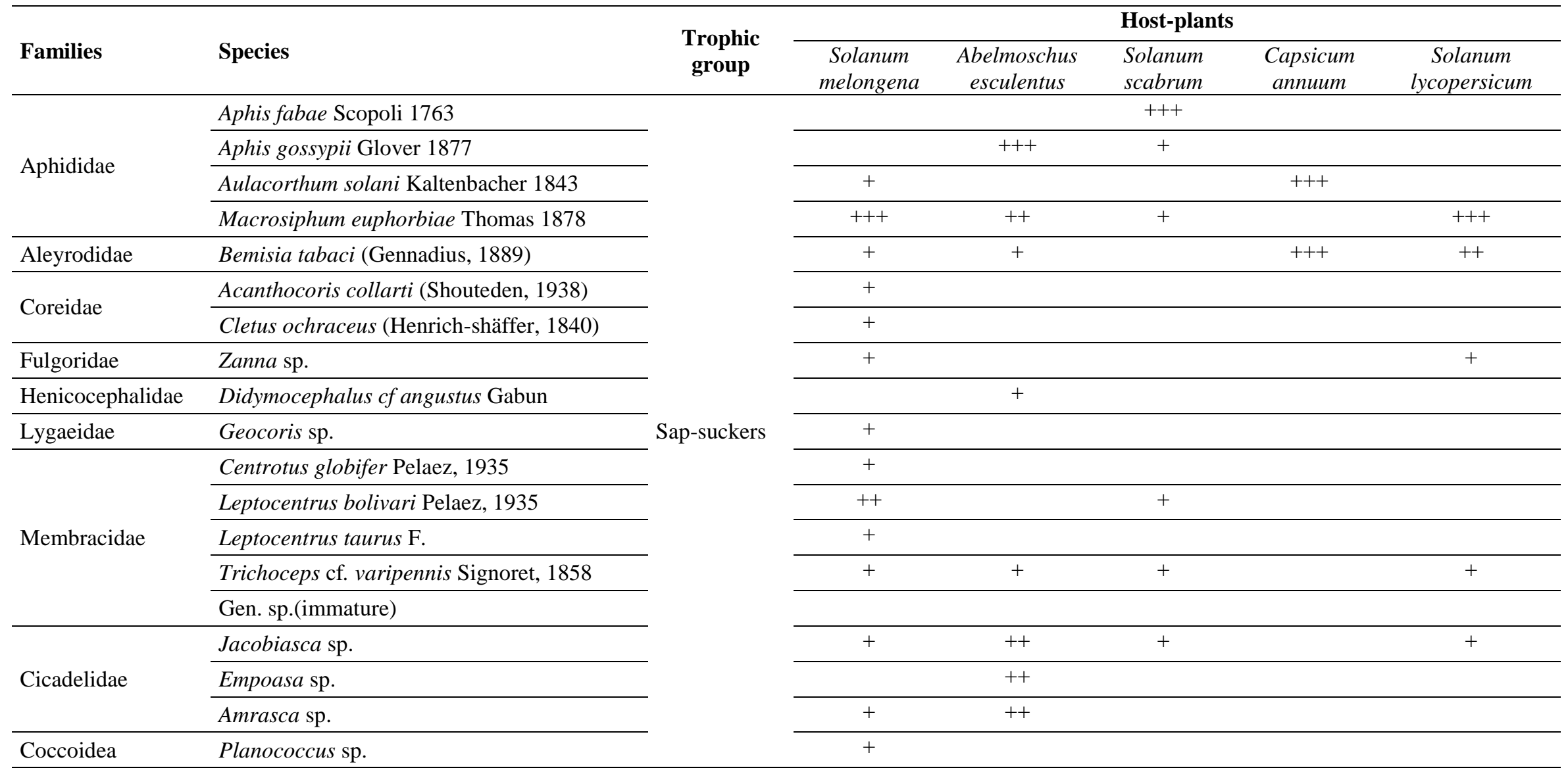


D. C. ALENE et al. / Int. J. Biol. Chem. Sci. 13(3): 1669-1681, 2019

\begin{tabular}{|c|c|c|c|c|c|}
\hline & Phenacoccus sp. & + & + & + & \\
\hline & Orthezia insignis Browne 1887 & & & ++ & \\
\hline \multirow{3}{*}{ Miridae } & Dearocoris sp. & + & & + & \\
\hline & Helopeltis schoutedeni Reuter & & & + & \\
\hline & Proboscidocoris fuliginosus & + & & & \\
\hline \multirow{2}{*}{ Pentatomidae } & Aspavia hastator & + & & & \\
\hline & Carbula melacantha $\mathrm{F}$. & + & & + & + \\
\hline \multirow{2}{*}{ Pyrrhocoridae } & Dysdercus voelkeri Schmidt & & + & & \\
\hline & Dysdercus melanoderes Karsck & & + & & \\
\hline \multirow{2}{*}{ Reduviidae } & Phonoctonus sp. & + & + & & \\
\hline & Rhynocoris sp. & & & + & + \\
\hline
\end{tabular}


D. C. ALENE et al. / Int. J. Biol. Chem. Sci. 13(3): 1669-1681, 2019

Table 2: Biodiversity indices in Hemiptera fauna associated with studied plant at Nkolondom market crop garden.

\begin{tabular}{lllllll}
\hline \multirow{2}{*}{ Indices } & \multicolumn{5}{c}{ Host-plants } & \\
\cline { 2 - 7 } & $\begin{array}{l}\text { Solanum } \\
\text { melongena }\end{array}$ & $\begin{array}{l}\text { Abelmoschus } \\
\text { esculentum }\end{array}$ & $\begin{array}{l}\text { Solanum } \\
\text { scabrum }\end{array}$ & $\begin{array}{l}\text { Capsicum } \\
\text { annuum }\end{array}$ & $\begin{array}{l}\text { Solanum } \\
\text { lycopersicum }\end{array}$ \\
\hline $\mathrm{S}$ & $22(3.57 \pm 1.48)^{\mathbf{a}}$ & $8(1.6 \pm 0.67)^{\mathbf{b}}$ & $7(1.52 \pm 0.68)^{\mathbf{b}}$ & $10(2 \pm 0.87)^{\mathbf{b}}$ & $13(1.8 \pm 0.71)^{\mathbf{b}}$ & $\chi^{2}=47.968 ; \mathrm{p}<0.0001 * * *$ \\
$\mathrm{H}^{\prime}$ & $1.17(0.76 \pm 0.38)^{\mathbf{a}}$ & $0.76(0.33 \pm 0.35)^{\mathbf{b}}$ & $0.47(0.22 \pm 0.29)^{\mathbf{b}}$ & $0.66(0.36 \pm 0.28)^{\mathbf{b}}$ & $0.51(0.27 \pm 0.24)^{\mathbf{b}}$ & $\chi^{2}=32.735 ; \mathrm{p}<0.0001 * * *$ \\
$\mathrm{Hmax}$ & $3.09(1.18 \pm 0.44)^{\mathbf{a}}$ & $2.08(0.39 \pm 0.41)^{\mathbf{b}}$ & $1.95(0.33 \pm 0.41)^{\mathbf{b}}$ & $2.30(0.6 \pm 0.45)^{\mathbf{b}}$ & $2.56(0.51 \pm 0.42)^{\mathbf{b}}$ & $\chi^{2}=47.968 ; \mathrm{p}<0.0001 * * *$ \\
$\mathrm{~J}$ & $0.38(0.62 \pm 0.13)^{\mathbf{a}}$ & $0.36(0.85 \pm 0.08)^{\mathbf{b}}$ & $0.24(0.67 \pm 0.1)^{\mathbf{a}}$ & $2.29(0.59 \pm 0.1)^{\mathbf{a c}}$ & $0.20(0.54 \pm 0.06)^{\mathbf{a c}}$ & $\chi^{2}=80.845 ; \mathrm{p}<0.0001 * * *$
\end{tabular}

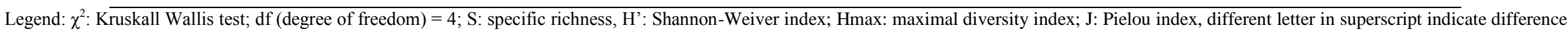
or similitude between indices in pairs of host-plant species after pairwise comparisons.

Table 3: Comparison of aphid fauna composition on different host-plants by the ANOSIM test on different host-plants.

\begin{tabular}{|c|c|c|c|c|c|c|}
\hline \multirow[b]{2}{*}{ Aphids species } & \multicolumn{5}{|c|}{ Plant species } & \multirow[b]{2}{*}{$\chi^{2}$ test } \\
\hline & $\begin{array}{l}\text { Solanum } \\
\text { melongena }\end{array}$ & $\begin{array}{l}\text { Abelmoschus } \\
\text { esculentus }\end{array}$ & $\begin{array}{l}\text { Solanum } \\
\text { scabrum }\end{array}$ & $\begin{array}{l}\text { Capsicum } \\
\text { annuum }\end{array}$ & $\begin{array}{l}\text { Solanum } \\
\text { lycopersicum }\end{array}$ & \\
\hline Aphis gossypii & $3(25.00)$ & $8(100.00)$ & $3(50.0)$ & $6(50.00)$ & $4(40.00)$ & $\chi^{2}=14.633 ; \mathrm{p}=5.527 \times 10^{-3} * *$ \\
\hline Macrosiphum euphorbiae & $12(100)$ & $5(62.50)$ & $0(0.00)$ & $3(25.00)$ & $10(100.00)$ & $\chi^{2}=39.429 ; p=5.68 \times 10^{-8} * * *$ \\
\hline Aphis fabae & $4(33.33)$ & $0(0.00)$ & $6(100)$ & $3(25.00)$ & $1(10.00)$ & $\chi^{2}=22.675 ; \mathrm{p}=0.000147 * * *$ \\
\hline Aulacorthum solani & $6(50.00)$ & $0(00.00)$ & $0(0.00)$ & $12(100.00)$ & $0(0.00)$ & $\chi^{2}=46.875 ; \mathrm{p}=1.619 \times 10^{-9} * * *$ \\
\hline $\mathrm{N}$ & 12 & 8 & 6 & 12 & 10 & \\
\hline
\end{tabular}


Table 4: Occurrence and frequency of ant recorded from the studied plants.

\begin{tabular}{|c|c|c|c|c|c|c|}
\hline \multicolumn{2}{|r|}{ Ants } & \multicolumn{5}{|c|}{ Plant species } \\
\hline Sub-families & Species & $\begin{array}{l}\text { Solanum } \\
\text { melongena }\end{array}$ & $\begin{array}{l}\text { Abelmoschus } \\
\text { esculentus }\end{array}$ & $\begin{array}{l}\text { Solanum } \\
\text { scabrum }\end{array}$ & $\begin{array}{l}\text { Capsicum } \\
\text { annuum }\end{array}$ & $\begin{array}{l}\text { Solanum } \\
\text { lycopersicum }\end{array}$ \\
\hline & Campontus flavomarinatus Mayr, 1862 & $9(50.00)$ & $2(11.11)$ & $6(33.33)$ & $6(33.33)$ & $4(22.22)$ \\
\hline \multirow{2}{*}{ Formicinae } & Campontus maculatus Fabricius, 1782 & $1(5.56)$ & $0(0.00)$ & $0(0.00)$ & $0(0.00)$ & $0(0.00)$ \\
\hline & Lepisiota $\mathrm{sp}$. & $0(0.00)$ & $0(0.00)$ & $1(5.56)$ & $0(0.00)$ & $0(0.00)$ \\
\hline \multirow{8}{*}{ Myrmicinae } & Myrmicaria opaciventris Emery, 1893 & $8(44.44)$ & $6(33.33)$ & $6(33.33)$ & 7 (38.89) & $5(27.78)$ \\
\hline & Pheidole megacephala Fabricius, 1793, & 7 (38.89) & $5(27.78)$ & $1(5.56)$ & $5(27.78)$ & $3(16.67)$ \\
\hline & Pheidole speculifera Emery, 1877 & $0(0.00)$ & $4(22.22)$ & $0(0.00)$ & $0(0.00)$ & $0(0.00)$ \\
\hline & Pheidole sp. & $0(0.00)$ & $0(0.00)$ & $0(0.00)$ & $1(5.56)$ & $0(0.00)$ \\
\hline & Monomoriun bicolor Emery, 1877 & $2(11.11)$ & $0(0.00)$ & $0(0.00)$ & $0(0.00)$ & $2(11.11)$ \\
\hline & Tertramurium sericiventre Emery, 1877 & $4(22.22)$ & $0(0.00)$ & $2(11.11)$ & $1(5.56)$ & $1(5.56)$ \\
\hline & Tertramurium sp. & $3(16.67)$ & $0(0.00)$ & $0(0.00)$ & $0(0.00)$ & $0(0.00)$ \\
\hline & Cardiocondyla sp. & $1(5.56)$ & $0(0.00)$ & $0(0.00)$ & $0(0.00)$ & $0(0.00)$ \\
\hline \multirow{3}{*}{ Dolichoderinae } & Axinidris sp. & $0(0.00)$ & $1(5.56)$ & $0(0.00)$ & $2(11.11)$ & $0(0.00)$ \\
\hline & Tapinoma sp. & $3(16.67)$ & $0(0.00)$ & $0(0.00)$ & $1(5.56)$ & $0(0.00)$ \\
\hline & Technomyrmex sp. & $0(0.00)$ & 7 (38.89) & $3(16.67)$ & $0(0.00)$ & $4(22.22)$ \\
\hline
\end{tabular}

Legend: In cells, the first figure is the number of occurrence and the second in brackets the relative frequency of occurrence. 


\section{DISCUSSION}

From the present study, it appeared that $S$. melongena supported the richest and the most diversified community. Furthermore, its fauna composition was somewhat different from that of the other plant species. This might be related to the fact that eggplant is among exotic plant in Cameroon market-oriented crop systems on one hand and then may not yet developed an intrinsic defence system against solanum pest. On the other hand, as in selected vegetable variety, continuous selections may have profoundly affected the natural ability of plants to overcome pest attacks through alteration of secondary metabolites secretions (Chen et al., 2018). As for the evenness, insect community of $A$. esculentus was different from that of the other studied plants. This could be due to the fact that it belongs to a different family (Malvaceae).

The hemipterans' families Coccidae, Aleyrodidae (Bemisia tabaci), and Aphididae (A. fabae, M. euphorbiae, A. gossypii, Aulacorthum solani) were observed in more or less large colonies. The greatest ones were those of aphids that could affect the productivity of their host-plants. Honeydew they produced might favour the development of sooty mold that would cover the leaves surface, thus disrupting photosynthesis process.

As for Membracidae, some of them were already recorded on S. melongena in large colonies on the study site (DjiétoLordon et al., 2007). In the present study, they were in small size colonies and identified as Centrotus globifer Pelaez, Leptocentrus bolivari Pelaez, Leptocentrus taurus F. and Tricoceps cf. varipennis Signoret. Differences in colony size may be linked to the scarcity of their members, which determine very irregular spatiotemporal variations. Anyway, these treehoppers are well known on Solanum species (Moreira and Del-Claro, 2005). The whiteflies, B. tabaci, showed preference for $C$. annuum. This has already been noted by Bordat \& Avanitakis (2004), Djiéto-Lordon et al. (2007). Youdeowei (2004) also observed a great outbreak of whiteflies on $C$. annuum and on Cucurbit species in Ghana. The incidence of this whitefly is well known on tomato (Mishra et al., 2017).

The family Cicadelidae was represented by three species from three genera, Jacobiasca sp., Empoasa sp., Amrasca sp. They occurred seldom on okra, eggplant, and sometimes on African nightshade. Yet members of the genus Amrasca are common on Cotton, okra and eggplant and are reported to be economically harmful abroad (Sharma and Singh 2002; Sahito et al., 2018).

The aphids, A. fabae, A. gossypii, Au. Solani were preferentially associated with $S$. scabrum, $A$. esculentus and $C$. annuum respectively. However, M. euphobiae was predominantly found on $S$. melongena and $S$. lycopersicum. Djiéto-Lordon et al. (2007) previously observed it on the same plants in addition to Vernonia amygdalina Delile (Asteraceae). This highlight the polyphagous feature of this green aphid. The same behavior was noticed for all aphid species observed in the present study. Based on this feature, they are regarded as polyphagous by Blackman \& Eastop (2000).

Direct damage caused by these aphids such as crinkled leaves and / or deformation of fruits, were similar to those observed respectively by Bordat \& Arvanitakis (2004) on vegetable crops in West and Central Africa, Mayotte and Réunion islands.

In the present study, the ants $M$. opaciventris, C. flavomarginatus, $P$. megacephala, and Tapinoma sp. were frequently observed patrolling all the studied plants, as they were seeking hemipterans' colonies. This had already been noticed by Djiéto-Lordon et al. (2007) who highlighted frequent interactions between these honeydew feeding ants and various hemipteran species.

\section{Conclusion}

The present study revealed a great diversified fauna of sap-sucking insects (Hemiptera) and ants (Formicidae) which were often simultaneously present on the 
target host-plants. The hemipteran community was dominated by aphids whereas the ant community was dominated by Camponotus flavomarginatus, Myrmicaria opaciventris, Pheidole megacephala and Technomyrmex sp. The eggplant, Solanum melongena, was the most diversified habitat, probably due to its exotic origin and its selected status. Data collected will be useful in understanding ant-hemipteran association pattern and designing some insects' management strategies in market-gardening based agro-system.

\section{COMPETING INTERESTS}

The authors declare that they have no competing interests.

\section{AUTHORS' CONTRIBUTIONS}

DCA and CDL conceived the project, DCA and YMM collected data and ZT did statistical analyses. DCA wrote the manuscript and all the co-authors read and approved the manuscript.

\section{ACKNOWLEDGEMENTS}

The present study was conducted without any financial are grateful to late $\mathrm{Mr}$ Léonard Enama Ngah, a dweller of Nkolondom who agreed to lend us a piece of land for field works.

\section{REFERENCES}

Blackman RL, Eastop VP. 2000. Aphids of the World's Crops. An Identification and Information Guide ( $2^{\text {nd }}$ edition). John Wiley: Chichester, London.

Bolton B. 1994. Identification Guide to the Ant Genera of the World. Harvard University Press : Cambridge.

Bordat D, Arvanitakis L. 2004. Arthropodes des cultures légumières d'Afrique de l'Ouest, centrale, Mayotte et Réunion. CIRAD, Montpellier, France.

Brault V, Uzest M, Monsion B, Jacquot E, Blanc S. 2010. Aphids as transport devices for plant viruses. Comptes Rendues Biologies, 333 (6-7): 524-538. DOI: https://doi.org/10.1016/j.crvi.2010.04.0
01.

Camara M, Sarr SM, Sarr I, Noba K. 2016. Caractérisations morphologique et génétique d'espèces d'aleurodes prélevées dans les cultures de tomate atteinte de la virose du TYLC, dans la zone des Niayes au Sénégal. International Journal of Biological and Chemical Sciences, 10(4): 1562-1572. DOI: http://dx.doi.org/10.4314/ijbcs.v10i4.9.

Chen YH, Ruiz-Arocho J, Von Wettberg EJB. 2018. Crop domestication: anthropogenic effects on insect-plant interactions in agroecosystems. Current Opinion in Insect Sciences, 29: 56-63. DOI:

https://doi.org/10.1016/j.cois.2018.06.0 04.

Clark AJ, Perry KL. Transmissibility of field isolates of soybean viruses by Aphis glycines. Plant Disease, 86: 1219-1222. DOI:

https://doi.org/10.1094/PDIS.2002.86.1 1.1219 .

Cooper WR, Dillwith JW, Puterka GJ. 2010. Salivary proteins of Russian wheat Aphid (Hemiptera: Aphididae). Environmental Entomology (Physiological Ecology), 39(1): 223231. DOI: https://doi.org/10.1603/EN09079.

Couilloud R. 1989. Hétéroptères déprédateurs du Cotonnier en Afrique et à Madagascar (Pyrrhocoridae, Pentatomidae, Coreidae, Alydidae, Rhopalidae, Lygaeidae). Coton et Fibres Tropicales, 64(3): 185-225.

Crawley MJ. 2007. The R book. John Wiley \& Sons Ltd, The Atrium, Southern Gate, Chichester, West Sussex PO19 8SQ, England, 951 p.

Davis JA, Radcliffe EB, Ragsdale DW. 2005. Soybean aphid, Aphis glycines, a new vector of Potato virus $\mathrm{Y}$ in potato. American Journal of Potato Research, 82: 197-201. https://doi.org/10.1007/BF02853585.

Delabie JHC. 2001. Trophobiosis between Formicidae and Hemiptera (Sternorrhyncha and Auchenorrhyncha): 
an overview. Neotropical Entomology, 30: 501-516. DOI: https://doi.org/10.1590/S1519566X2001000400001.

Djiéto-Lordon C, Aléné DC, Reboul J. 2007. Contribution à la connaissance des insectes associés aux cultures maraîchères dans les environs de Yaoundé-Cameroun. Cameroon Journal of Biological and Biochemical Sciences, 15: 1-13.

Djiéto-Lordon C, Heumou CR, Elono Azang PS, Alene CD, Ngueng AC, Ngassam P. 2014. Assessment of pest insects of Capsicum annuum L.1753 (Solanaceae) in a cultivation cycle in Yaoundé. International Journal of Biological and Chemical Sciences, 8(2): 621-632. DOI: https://doi.org/10.4314/ijbcs.v8i2.2.

Elono Azang PS, Aléné DC, Heumou CR., Ngassam P, Djiéto-Lordon C. 2016. Diversity, abundance and incidence of fruit pest insects on three Solanum varieties (Solanaceae) in two agroecological zones of Southern Cameroon. African Journal of Agricultural Research, 11(39): 37883798.

DOI: https://doi.org/10.5897/AJAR2016.1120 6.

Gildow FE, Shah DA, Sackett WM, Butzler T, Nault BA, Fleischer SJ. 2008. Transmission efficiency of Cucumber mosaic virus by aphids associated with virus epidemics in snap bean. Phytopathology, 98: 1233-1241. DOI: https://doi.org/10.1094/PHYTO-98-111233.

Guerrieri E, Digilio MC. 2008. Aphid-plant interactions: a review. Journal of Plant Interactions, 3(4): 223-232. DOI: http://dx.doi.org/10.1080/17429140802 $\underline{567173}$.

Heumou CR, Djiéto-Lordon C, Aléné DC, Elono Azang PS. 2015. Diversity and agronomic status of tomato and pepper fruit pests in two agro-ecological zones of southern Cameroon: Western Highland and Sothern plateau of Cameroon. African Journal of Agricultural Research, 10(11): 1224-
1232.

DOI: https://doi.org/10.5897/AJAR2013.8254

Hill JH, Alleman R, Hogg DB, Grau CR. 2001. First Report of Transmission of Soybean Mosaic Virus and Alfalfa Mosaic Virus by Aphis glycines in the New World. Plant Disease, 85(5): 561561.

DOI: https://doi.org/10.1094/PDIS.2001.85.5. $561 \mathrm{C}$.

Hölldobler B, Wilson, EO. 1990. The Ants. The Belknap Press of Harvard University: Cambridge, Massachusetts; 732.

Kahane R, Temple L. 2004. Place et rôle de l'agriculture périurbaine en Afrique tropicale. Rapport interne, CIRAD.

Mahob RJ, Ndoumbè-Nkeng M, Ten Hoopen GM, Dibog L, Nyassé S, Rutherford M, Mbenoun M, Babin R, Amang a. Mbang, J, Yede, Bilong Bilong, CF. 2014. Pesticides use in cocoa sector in Cameroon: characterization of supply source, nature of actives ingredients, fashion and reasons for their utilization. International Journal of Biological and Chemical Sciences, 8(5): 1976-1989. DOI:

http://dx.doi.org/10.4314/ijbcs.v8i5.3.

Mahob RJ, Nsoga Etam P B, Dibog L, Babin R, Voula AV, Begoude D., Fotso Toguem YG, Baleba L, Owona Ndongo PA, Bilong Bilong CF. 2018. Assessment of the effect of cocoa mosquito mirid true bug, Helopeltis sp. (Hemiptera: Miridae) on the cocoa (Theobroma cacao L.) production in Cameroon (Central Africa). International Journal of Biological and Chemical Sciences, 12(4): 1865-1875. DOI: https://dx.doi.org/10.4314/ijbcs.v12i4.2 7

Moreira VSS, Del-Claro K. 2005. The outcomes of an ant-treehopper association on Solanum lycocarpum St. Hill: increased membracid fecundity and reduced damage by chewing Herbivores. Neotropical Entomology, 34(6): $\quad 881-887 . \quad$ DOI: https://doi.org/10.1590/S1519- 


\section{X2005000600002.}

Mvogo C. 2005. Référentiel technicoéconomique du maraîchage périurbain à Yaoundé. Mémoire de fin d'étude. Université de Dschang.Ng JCK, Perry KL. 2004. Transmission of plant viruses by aphid vectors. Molecular Plant Pathology, 5(5): 505-511. DOI: https://doi.org/10.1111/J.13643703.2004.00240.X.

Oksanen, JFG, Blanchet R, Kindt P, Legendre PR, Minchin RB, O'Hara GL, Simpson M, Solymos P, Stevens HH, Wagner AH. 2011. Vegan: Community Ecology Package. R package version 2.0-2. project.org/package= $=$ vegan.

Oliver TH, Mashanova A, Leather SR, Cook JM, Jasen VAA. 2007. Ant semiochemicals limit apterous aphid dispersal. Proceedings of the Royal Society $B, \quad \mathbf{2 7 4}(1629)$ : $\quad 3127-3131$. DOI: https://doi.org/10.1098/rsp b.2007.1251.

Sahito HA, Soomro F, Kousar T, Shah ZH, Mangrio WM. 2018. Population management of cotton Jassid, Amrasca biguttula biguttula Ishida through its biological control agent, Arescon enocki (Rao and Kaur) under field and laboratory conditions at upper Sindh, Pakistan. International Journal of Biosciences, 13(2): 210-216. DOI: http://dx.doi.org/10.12692/ijb/13.2.210216.

Sharma A, Singh R. 2002. Oviposition preference of cotton leafhopper in relation to leaf-vein morphology. Journal of Applied Entomology, 126:
538-544. https://doi.org/10.1046/j.14390418.2002.00697.x.

Steiner FM, Schlick-Steiner BC, Holzinger WE, Komposch C, Pazoutova S, Sanetra M, Christian E. 2004. A novel relationship between ants and a leafhopper (Hymenoptera: Formicidae; Hemiptera: Cicadellidae). European Journal of Entomology, 101(4): 689692.

DOI: https://doi.org/10.14411/eje.2004.090.

Suchel JB. 1988. Les climats du Cameroun V3. Domaine des climats subéquatoriaux et équatoriaux. Thèse de Doctorat d'État. Université de saintEtienne. 1188p.

Taylor (http:/www.antbase.org/, April, 06 ${ }^{\text {th }}$, 2015)

Temple L. 2001. Quantifications des productions et des échanges de fruits et légumes au Cameroun. Cahiers Agricultures, 10 : 87-94.

Temple L, Marquis S, Simon S. 2008. Le maraîchage périurbain à Yaoundé est-il un système de production localisé innovant? Economies et Sociétés, série Agroalimentaire : 2309-2328. < hal$00384377>$

Wei T, Simko V. 2017. R package "corrplot": Visualization of a Correlation Matrix (Version $0.84)$. https://github.com/taiyun/corrplot.

Youdeowei A. 2004. Principes de la lutte

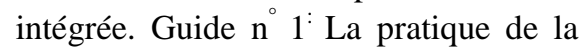
lutte intégrée en production maraîchère. PPRSD, Accra. 49 p. 